\title{
Christian Godoi \\ Violência celular: produção de sentido na recepção e uso dos telefones móveis
}

\section{Resumo}

O reconhecimento da presença generalizada do celular na vida cotidiana das pessoas acentua caminho novo de expressão hoje da socialização mas também de mecanismos simbólicos onde a violência encontra novas formas de se objetivar. $\mathrm{O}$ presente texto introduz reflexões que retomam os sentidos da violência mediados agora pelo acesso e uso de micro tecnologias da comunicação no contexto da contemporaneidade social em mutação.

\section{Um caminho da violência}

Não são poucos os lugares dos quais se pode observar a violência: ontologicamente e sob a ótica da linguagem, psicanaliticamente, cultural, sociológica, antropológica e mediaticamente. Na aurora do século 21, a partir do advento de acesso das mais variadas comunidades às novas tecnologias, surge a violência cibercultural, virtual, micro-tecnológica. Mas será possível encontrar motivadores da violência comuns a todas essas esferas? Pode-se apontar um lugar híbrido no qual essa violência se apresente?

Primeiramente, cabe esclarecer que não se quer aqui apontar à violência um caráter maniqueísta (não se quer descrever ou encontrar bem e mal, certo e errado). É portanto necessário excluir desse estudo a violência em âmbito filosófico, ontológico, pois este permitiria as mais variadas especulações em torno do objeto.

No que tange ao percurso histórico do que se considera violência, as discussões sobre períodos específicos ou personagens que fujam da temática pertinente a esta reflexão também são suprimidas. Hitler, holocausto, fascismo, revoluções na era moderna, são retomados aqui, quando o são, somente como referência a um período específico, não enquanto causa/efeito. Quer-se com isso enfocar diretamente um fenômeno atual que intensifica a sensação, através do uso de micro-tecnologias, da violência como algo natural a ponto de passar despercebida àqueles que a cometem e aos que dela são vítimas.

A hibridação tecnológica fornece caminhos não somente para o desenvolvimento de relações, para a distribuição de informação, ou para a localização de alteridades. Ela transformou-se em uma estrutura, um sistema no qual as ações acontecem independentemente dos indivíduos. É um outro espaço que determina tempos paralelos ao mundo vivido (mas faz parte também do mundo real, pois forma-se graças a ele e se expande em sua esfera). Quando se percebe o sistema formado pelas micro-tecnologias evidencia-se de imediato a existência de relações de poder, de força, ou econômicas.
Christian Godoi é Pós-Graduando do Programa de Pós Graduação em Comunicação da Universidade Católica de Santos, e professor de Jornalismo e Publicidade na UNISANTA.

christiangodoi@hotmail.com 
No mundo ocidentalizado transnacional, dependente de uma economia globalizada, interligado por redes tecnológicas de informação, altamente complexo, desenvolvido a partir da idéia de emancipação humana através da razão, do projeto de modernidade, pode-se conceituar a violência a priori como "o exercício da força física e da coação psíquica para obrigar alguém a fazer alguma coisa contrária a si, contrária aos seus interesses e desejos, contrária ao seu corpo e à sua consciência, causando-lhe danos profundos e irreparáveis, como a morte a loucura, a auto-agressão ou a agressão aos outros" (Chauí, p.336, 337). Contudo, a violência, por não ser restrita somente à esfera física ou psicológica, adquire também simbolicamente inúmeras formas desconhecidas de quem por ela é vitimado, mas se dá intencionalmente por quem a produz.

\section{Estrutura da violência celular}

Um objeto micro-tecnológico de grande destaque pelas suas características híbridas atualmente é o telefone celular. Ainda que não tenha funções semelhantes ao redor do mundo (é impossível comparar suas funções e usos no Japão, China e Europa -- bem como o avanço de recursos com a chegada do iPhone nos EUA --, com a utilização dos telefones móveis na América Latina), no Ocidente civilizado ele vem adquirindo espaço em todas as categorias sociais. Carrega consigo inúmeras funções físicas -- telefone móvel, agenda, máquina fotográfica, podcast, câmera de vídeo, despertador, dicionário, mensagens -- bem como traz uma carga simbólica extremamente importante - posicionamento social, status, pertencimento, objetivações - dentre as quais encontra-se também a violência em sua forma mais dissimulada.

Os estudos recentes desse objeto tecnológico móvel demonstram-no como uma prótese nômade, descrevem ações por ele facilitadas do ponto de vista, em geral, do emissor/usuário dentro um ambiente cibercultural-remix ; a partir daí, pode-se apontar, desde já, algumas formas de violência físicas (atentados terroristas através de detonadores celulares, seqüestros, extorsão, comando de quadrilhas, de ações criminosas, de assaltos, tudo pelo aparelho móvel de dentro de presídios) e simbólicas (a invasão da propriedade intelectual, a reformulação da obra de arte, a reconfiguração e a apropriação do texto, a utilização da imagem sem permissão, a intrusão, a invasão de privacidade).

Contudo, ampliando ainda mais o foco pode-se apontar a violência do celular vista por outra esfera, também simbólica, através da qual a estrutura do capital (os detentores das concessões de exploração comercial da telefonia móvel e o fabricante dos aparelhos) simula a inclusão de qualquer individuo na evolução e no desenvolvimento do seu tempo e espaço ao supervalorizar o material produzido por ele em texto, som ou imagem, tornando esse material público e super-dimensionando sua repercussão graças à conivência dos media de massa (estes reféns do poderio das empresas anunciantes). Tem-se, com isso, a impressão de que todos podem ser diretores, atores, jornalistas, escritores, artistas, sendo que para o capital, tudo não passa da manutenção da fidelidade do usuário à marca. É o seqüestro do usuário, seu aprisionamento às opções oferecidas pelo seu operador.

Entretanto, o interesse maior neste estudo é no que se processa no campo de recepção/usuária, a partir da utilização de um objeto micro-tecnológico-protético-nômade em um país no qual as diferenças e desigualdades são agora também 
reguladas pelo grau de conexão com o universo digital de informações. É apontar a possibilidade de ser violentado a partir desse objeto adquirido para a satisfação de alguns desejos criados pelo mercado, pela sociedade e pelos media de massa.

\section{Violência simbólica digital-móvel}

A publicização do mundo privado se dá indiscriminadamente através do celular sem que seus usuários percebam sua exposição constante. Como primeira forma de violência após a aquisição do artefato: a possibilidade de ser localizado através da triangulação de antenas, quando o equipamento é desprovido de GPS (Sistema de Posicionamento Global - privilégio maior de Japoneses e Europeus); outra possibilidade de se ver o mundo privado invadido é pela disponibilidade do material escrito nas mensagens de texto ser acessível, seja por funcionários das empresas de telefonia, seja pelas autoridades (fato bastante comum na investigação de crimes nos EUA, possível também na América Latina). O identificador de chamada é outra forma de violência, pois exclui o outro que, quando reconhecido, não é atendido.

No entanto, é na esfera simbólica o lugar de o receptor usuário ser vítima constante sem que se dê conta disso. O estupro da atenção quando o aparelho toca ou vibra durante aulas, palestras sessões de cinema; a possibilidade de ser rastreado e denunciado pelo registro de chamadas. Ser vítima de câmeras fotográficas, filmadoras em todo e qualquer lugar acarreta a possibilidade de, posteriormente, ter a imagem distribuída em rede ao redor do mundo; a incessante recepção de mensagens indesejadas (fato comum na web) é por vezes invasiva; bem como ações aparentemente simples, como o jogo, podem transformar-se num vício; pode-se citar também o compromisso constante com o mundo trabalho, um novo modelo de escravidão; ou o monitoramento de adolescentes pela família; e mais, a dependência de capital para a manutenção do status.

Quando se observa a partir da antropologia ou da sociologia alguns modelos de violência (rituais de sacrifício, culturas antropofágicas, imposição da conquista pela força ou guerras e revoluções), percebem-se diferentes graus de significação dados pelo outro externo a eles, mas para o ator dos atos violentos esses significados podem ser configurações de pertença, seja à esfera de vida, à social, à de poder ou à econômica.

E é exatamente a partir do sentimento de pertença que se constrói a tese aqui defendida: a de que o celular é um mediador comunicacional capaz de despertar no receptor/usuário a objetivação de si através de sua aquisição e utilização como mecanismo de pertença (pertença e objetivação de si serão mais bem definidas no tópico 5 do presente texto); esta no entanto não se efetiva e funciona mais como uma fantasia de que através das tecnologias-móveis-protéticas possa-se ter uma voz ativa fora de sua ambiência ciberespacial.

Um mecanismo eficaz de aceitação da condição servil e a obliteração da crítica pelo discurso de disponibilidade da informação (em detrimento do conhecimento). Essa obliteração é vista aqui como a mais violenta ação do celular no usuário/receptor. 


\section{Ações organizadas nômades}

O telefone móvel é, até o momento, a forma mais dinâmica de manter relações mediada a distância, não somente pela portabilidade e pela mobilidade, mas, em especial no Brasil, pela facilidade de aquisição. Graças ao custo do aparelho e aos planos pré-pagos mais de 100 milhões de aparelhos circulam no país, hoje com mais de 185 milhões de habitantes, mais de um aparelho para cada dois brasileiros, um fenômeno impressionante que insta à busca de sua causa. $\mathrm{O}$ senso comum atribui de imediato à necessidade de comunicação (por quê? Com quem?) do usuário o número elevado de celulares, fato questionável já que boa parte dos aparelhos não recebe recarga constantemente, depende, pois, somente de receber chamadas. Outras opiniões levam a conclusão da necessidade de alguns em possuir o aparelho como forma de status, que o leva a ter a impressão de fazer parte de grupos em ascensão.

Estudos atualizados, contudo, mostram uma diferença abissal entre os usos que se faz dos celulares e de suas funções no Brasil em comparação ao que se vê no Japão e Europa, lugares nos quais o aparelho está naturalmente conectado à Internet, possibilita portanto a captura de músicas para armazená-las no pod cast hibridado, além disso permite pagamentos como um cartão de crédito e efetua operações bancárias. Os telefones celulares atuais de terceira geração, aponta Souza e Silva (in: Correia Araújo, 2006), "incluem acesso à Internet com banda larga, mensagens multimídia, mensagens de texto, câmera digital e sistemas de posicionamento (GPS)". Essas tecnologias ainda estão engatinhando no Brasil e na América Latina, apesar de uma minoria financeiramente estável possuir aparelhos com pod cast ou câmeras e buscar produzir, eventualmente, alguma expressão artística com elas. No entanto, o brasileiro está longe de poder participar -- por falta de tecnologia, esta uma forma de violência excludente a partir das ambições mercadológicas -- de jogos como Botfighters e Mogi , bem como não tem interesse e maturidade em suas relações com as novas tecnologias a ponto de desenvolver manifestações como os flash mobs, seja para performances teatrais, seja para ações políticas.

As limitações do celular do receptor/usuário no país levam-no portanto a somente receber ligações (violência econômica excludente), eventualmente a operar alguns jogos instalados no aparelho, e à expectativa de que alguma promoção da operadora refaça sua existência enquanto emissor/usuário. Cria-se um favelado digital, dependente da sucata barata que o marginaliza. Sendo assim, o que torna afinal, simbolicamente, essa tecnologia móvel tão sedutora? Retoma-se a objetivação de si enquanto mecanismo de efetivação da pertença como ponto fundamental.

\section{Objetivação de si e pertencimento}

O desejo de ser mais do que se é, ou de possuir algo além do que se tem, como forma de se ver inserido em uma determinada categoria de pessoas para ser reconhecido pelo grupo como um igual, este pode ser um dos conceitos de objetivação de si. É deixar de ser sujeito para ser objeto de si próprio. Esse fenômeno é mais facilmente perceptível nos mass media através da necessidade de alguns em conseguir a fama a qualquer custo, mas já operam em ambientes ciberculturais. Contudo, quando mecanismo de efetivação de pertença a objetivação de si é mais. Transforma-se numa forma de dar voz aos que pretendem criar seus próprios am- 
bientes, caso não sejam reconhecidos pelos seus diferentes, e não é somente uma fantasia tresloucada dos caçadores de fama.

Contrariamente à inclusão (operação na qual o grupo permite a inserção de um estranho sempre lembrando-o dessa permissão sem garantir-lhe voz) o sentimento de pertença leva à cidadania, tornando seu sujeito ator social, ainda que somente em seu espaço. Aliás, como lembra Sousa, "a questão do pertencimento não se vincula diretamente à cidadania, mas ao espaço público e através deste, sim, à cidadania." (Sousa, 1999, p. 20)

Além do espaço público habermasiano, hoje pode se remeter a outras noções construtivas do espaço, que vão expandi-lo para além de somente um campo de argumentação. Castells, por exemplo, defende o espaço de fluxos, ou seja, uma nova forma espacial de práticas sociais que "dominam uma sociedade em rede", bem como "uma organização material de práticas sociais temporalmente compartilhadas que funcionam através de fluxos"(Castells, 2000, p.442). Já Floris propõe o espaço público como campo de formação simbólica de uma opinião pública "através de todas as formas de comunicação existentes na sociedade", sendo ainda um espaço conflitivo que exprime relações sociais de desigualdade e dominação (Floris, 1995, p. 125).

Reconfiguração de práticas sociais, novas construções da opinião pública, formação simbólica, espaço de argumentação através de redes em deslocamento constante em um espaço físico; interação social, produção de sentido através de medias portáteis, é isso que se apresenta como novas possibilidades do telefonemóvel-híbrido, quando se desloca o eixo de observação das empresas produtoras, dos distribuidores, ou quando além do emissor/usuário parte-se também para a compreensão dos receptores/usuários, buscando elementos dos estudos de recepção a produtos mediáticos, e apontando-os agora para um objeto gerador, ainda que de maneira simbólica, de um sujeito diferenciado na relação com seu veículo/ media/instrumento/prótese. As relações podem se dar, também, na construção de ações específicas não mais mediadas pelas páginas, por programas, por terceiros, por horários, pela grade de programação ou pela audiência, por exemplo. O telefone celular e toda a complexidade que carrega consigo permite as mais variadas ações sociais diretas, dependendo principalmente da conscientização de suas possibilidades de usos.

Não atualizar a tecnologia com a mesma velocidade ao redor do mundo ou manter o usuário refém de lançamentos sazonais, com o intuito de atá-lo economicamente a uma empresa ou operadora, é o mais desprezível dos seqüestros realizados tecnologicamente. Da mesma forma que permitir a uma maioria sua presença em algum evento somente como figurante não é incluí-la, é manter a exclusão. Disponibilizar aparelhos sucateados, desprovidos de tecnologias não é democrático, é o desenvolvimento de uma favela digital e, espera-se que a esfera digital gere violência da mesma maneira que uma periferia física, já que ambas são vítimas das desigualdades.

O pertencimento não é, nem deve ser, a etapa final da configuração da cidadania, mas é um caminho importante para a conscientização do papel do indivíduo na sociedade.

Dessa forma, conclui-se que enquanto poderoso mecanismo no qual se forma, através de uma rede infinita, uma estrutura para além de somente o indivíduo, o 
celular e agora o iPhone conseguem incluir em si toda uma gama de significação. A violência física, dada pelas ações criminosas, fundamentalistas ou revolucionárias possíveis, bem como a simbólica -- a manutenção da distância daquele que não se quer perto, a ignorância, ações de inclusão ou formas distorcidas de pertencimento -- podem ser geradoras de conflitos sutis ou de expressões escancaradas de intolerância. Todavia, iniciado o reconhecimento dessas práticas nas atuais tecnologias e nas que virão posteriormente, quem sabe se formem novos modos de operação de relações sociais mais justas por intermédio de um objeto mediador de comunicação tão promissor.

\section{Bibliografia}

CORREA ARAUJO, Denize (org.). Imagem (ir)realidade: comunicação e cibermídia. Porto Alegre: Sulina, 2006.

CHAUÍ, Marilena. Convite à filosofia. São paulo: Ática, 2002.

CASTELLS, Manuel. The rise of the network society. Oxford; Malden, MA: Blackwell Publishers, 2000.

DAGNINO, Evelina (org.). Os movimentos sociais e a emergência de uma nova noção de cidadania. In: Os anos 90: política e sociedade no Brasil. São Paulo: Brasiliense, 2004.

FLORIS, Bernard. L'interpretation de l'espace public et de enterprise. In: PAILLIART, Isabelle (org.). L'espace public et l'emprise de la communication. Ellug: Grenoble, França, 1995.

SOUSA, Mauro Wilton de. Práticas de recepção mediática como práticas de pertencimento público. In: Novos Olhares: revista de estudos sobre práticas de recepção a produtos mediáticos. São Paulo: ECA/USP, 1999. 